\title{
THE HEREDITARY TRANSMISSION OF HEMOGLOBIN DIFFERENCES IN MICE ${ }^{1}$
}

\author{
By SALOME GLUECKSOHN-WAELSCH, HELEN M. RANNEY, AND \\ BETTY F. SISKEN
}

\author{
(From the Department of Anatomy, Albert Einstein College of Medicine, Yeshiva University, \\ and the Department of Medicine, College of Physicians and Surgeons, Columbia \\ University, New York City, N. Y.)
}

(Submitted for publication December 12, 1956; accepted January 31, 1957)

The existence, in inbred strains of mice, of two different types of electrophoretic hemoglobin patterns has been demonstrated with the method of paper electrophoresis (1). Preliminary studies of the distribution of these different patterns in the inbred strains tested indicated strongly a genetic basis of hemoglobin differences in mice. It is the purpose of the present communication to report the results of breeding experiments designed to test the assumption of a hereditary transmission of these differences and to determine the mode of inheritance.

\section{MATERIAL AND METHODS}

The determination of hemoglobin patterns was carried out by filter paper electrophoresis according to the method described (2). Two types of patterns as previously illustrated (1) were obtained, one apparently of a single homogeneous protein (Type I), and the other diffuse, apparently of more than one protein (Type II). No difficulty was encountered in distinguishing pattern I from pattern II; nevertheless, minor differences between the hemoglobin patterns of individual mice within Type I or of mice within Type II groups were noted (Figure 1). Therefore, classification of hemoglobin patterns as Type I or Type II does not necessarily imply that the hemoglobin or hemoglobins present were in each case absolutely identical.

The following inbred mouse strains with hemoglobin patterns as determined in previous studies (1) and indicated below were used for breeding experiments:

\begin{tabular}{clll} 
Strain No. & Strain name & \multicolumn{2}{c}{ Hemoglobin pattern } \\
1 & DBA/1 & diffuse (d) & Type II \\
2 & BALB/Glw & diffuse (d) & Type II \\
3 & Fused & diffuse (d) & Type II \\
4 & $\mathrm{C}_{3} \mathrm{H}$ & diffuse (d) & Type II \\
5 & Splotch & single (s) & Type I \\
6 & Kink I & single (s) & Type I \\
9 & Urogenital & single (s) & Type I
\end{tabular}

1 Part of the work reported in this paper was carried out at the Department of Obstetrics, College of Physicians and Surgeons, Columbia University, New York. This work was supported in part by a research grant (G3676) from the National Institutes of Health, Public
These strains were intercrossed in a number of different combinations as follows :

\begin{tabular}{cll} 
Strain Nos. & \multicolumn{1}{c}{ Strain names } & $\begin{array}{c}\text { Hemoglobin } \\
\text { pattern }\end{array}$ \\
$1 \times 4$ & DBA $/ 1 \times \mathrm{C}_{3} \mathrm{H}$ & $\mathrm{d} \times \mathrm{d}$ \\
$1 \times 6$ & DBA $/ 1 \times$ Kink I & $\mathrm{d} \times \mathrm{s}$ \\
$2 \times 5$ & BALB $\times$ Splotch & $\mathrm{d} \times \mathrm{s}$ \\
$3 \times 9$ & Fused $\times$ urogenital & $\mathrm{d} \times \mathrm{s}$ \\
$4 \times 5$ & $\mathrm{C}_{3} \mathrm{H} \times$ Splotch & $\mathrm{d} \times \mathrm{s}$ \\
$4 \times 6$ & $\mathrm{C}_{3} \mathrm{H} \times$ Kink I & $\mathrm{d} \times \mathrm{s}$ \\
$5 \times 9$ & Splotch $\times$ urogenital & $\mathrm{s} \times \mathrm{s}$ \\
$6 \times 9$ & Kink I $\times$ urogenital & $\mathrm{s} \times \mathrm{s}$
\end{tabular}

First $\left(F_{1}\right)$ and second $\left(F_{2}\right)$ hybrid generations as well as backcross generations were obtained and the hemoglobin patterns of the offspring tested. All animals were at least 2 months old before their hemoglobin was examined, in order to avoid any possible admixture of fetal hemoglobin.

Altogether, 635 specimens of hemoglobin were tested and distributed as follows:

$F_{1}$ generation: $\quad 140$

$F_{2}$ generation: $\quad 210$

Backcross of $F_{1}$ generation to parent: 102

Backcross of $F_{2}$ generation to parent: 183

635

\section{RESULTS}

The results obtained are summarized in Tables I to IV.

As shown in Table $I$, crosses of strains with "diffuse" type of hemoglobin pattern with those of "single" type (experiments 1 through 5) were made up in five different combinations. Altogether, 101 offspring were tested; the hemoglobin of all of them showed the "diffuse" type of pattern.

Crosses between different strains with the "diffuse" type of hemoglobin pattern (experiment 6)

Health Service, and in part by a grant-in-aid from the American Cancer Society upon recommendation of the Committee on Growth of the National Research Council.

2 The nomenclature used in the designation of mouse strains is based on the recommendations outlined by the Committee on Standardized Nomenclature for Inbred Strains of Mice (3). 
TABLE I

Results of intercrosses between d and s strains$F_{1}$ generation

\begin{tabular}{|c|c|c|c|c|c|}
\hline \multirow{2}{*}{$\begin{array}{l}\text { Exp. } \\
\\
1 \\
2 \\
3 \\
4 \\
5\end{array}$} & \multirow{2}{*}{\begin{tabular}{l}
\multicolumn{1}{c}{ Parents } \\
\\
DBA $\times \mathrm{Ki}$ \\
$\mathrm{BALB} \times \mathrm{Spl}$ \\
$\mathrm{Fu} \times \mathrm{ur}$ \\
$\mathrm{C}_{3} \mathrm{H} \times \mathrm{Spl}$ \\
$\mathrm{C}_{3} \mathrm{H} \times \mathrm{Ki}$
\end{tabular}} & \multirow{2}{*}{$\begin{array}{c}\begin{array}{c}\text { Strain } \\
\text { numbers }\end{array} \\
\\
1 \times 6 \\
2 \times 5 \\
3 \times 9 \\
4 \times 5 \\
4 \times 6\end{array}$} & \multirow{2}{*}{$\begin{array}{c}\begin{array}{c}\text { Parents' } \\
\text { hemoglobin } \\
\text { pattern }\end{array} \\
\\
\mathrm{d} \times \mathrm{s} \\
\mathrm{d} \times \mathrm{s} \\
\mathrm{d} \times \mathrm{s} \\
\mathrm{d} \times \mathrm{s} \\
\mathrm{d} \times \mathrm{s}\end{array}$} & \multicolumn{2}{|c|}{$\begin{array}{l}\text { Offspring's } \\
\text { hemoglobin } \\
\text { pattern }\end{array}$} \\
\hline & & & & $\begin{array}{c}\mathrm{d} \\
22 \\
17 \\
19 \\
19 \\
24\end{array}$ & $\begin{array}{l}\mathrm{s} \\
0 \\
0 \\
0 \\
0 \\
0\end{array}$ \\
\hline & All $F_{1} d \times s$ & & & 101 & 0 \\
\hline 6 & $\mathrm{DBA} \times \mathrm{C}_{3} \mathrm{H}$ & $1 \times 4$ & $d \times d$ & 23 & 0 \\
\hline & All $F_{1} d \times d$ & & & 23 & 0 \\
\hline $\begin{array}{l}7 \\
8\end{array}$ & $\begin{array}{l}\text { Spl } \times \text { ur } \\
\text { Ki } \times \text { ur }\end{array}$ & $\begin{array}{l}5 \times 9 \\
6 \times 9\end{array}$ & $\begin{array}{l}s \times s \\
s \times s\end{array}$ & $\begin{array}{l}0 \\
0\end{array}$ & $\begin{array}{r}10 \\
6\end{array}$ \\
\hline & All $F_{1} s \times s$ & & & 0 & 16 \\
\hline
\end{tabular}

gave 23 offspring with the "diffuse" type of hemoglobin pattern.

Finally, crosses were made between different strains with "single" type hemoglobin pattern (experiments 7 and 8) and all 16 offspring tested gave the "single" pattern.

Thus "diffuse" when crossed by "diffuse" gives "diffuse," and "single" by "single" gives "single," in the first hybrid generation. "Diffuse" when crossed by "single" gives "diffuse" which by paper electrophoresis is indistinguishable from "diffuse" of the original parent with the "diffuse" type of hemoglobin pattern.

TABLE II

Intercrosses between $d$ and strains $-F_{2}$ generation

\begin{tabular}{|c|c|c|c|c|}
\hline \multirow{2}{*}{$\begin{array}{l}\text { Exp.* } \\
\\
1 \\
2 \\
3 \\
4 \\
5\end{array}$} & \multirow{2}{*}{$\begin{array}{l}\text { Parents' origin } \\
\text { rom DBA (d) } \times \mathrm{Ki} \mathrm{(s)} \\
\text { rom BALB (d) } \times \mathrm{Spl}_{(\mathrm{s})} \\
\text { rom } \mathrm{Fu}(\mathrm{d}) \times \mathrm{ur}(\mathrm{s}) \\
\text { rom } \mathrm{C}_{3} \mathrm{H}(\mathrm{d}) \times \mathrm{Spl}(\mathrm{s}) \\
\text { rom } \mathrm{C}_{3} \mathrm{H}(\mathrm{d}) \times \mathrm{Ki}(\mathrm{s})\end{array}$} & \multirow{2}{*}{$\begin{array}{c}\begin{array}{c}\text { Parents' } \\
\text { hemoglobin } \\
\text { pattern }\end{array} \\
\text { d } \times d \\
\mathrm{~d} \times \mathrm{d} \\
\mathrm{d} \times \mathrm{d} \\
\mathrm{d} \times \mathrm{d} \\
\mathrm{d} \times \mathrm{d}\end{array}$} & \multicolumn{2}{|c|}{$\begin{array}{l}\text { Offspring's } \\
\text { hemoglobin } \\
\text { pattern }\end{array}$} \\
\hline & & & $\begin{array}{c}d \\
26 \\
21 \\
17 \\
19 \\
21\end{array}$ & $\begin{array}{r}\mathrm{s} \\
10 \\
7 \\
7 \\
11 \\
7\end{array}$ \\
\hline & All $F_{2}$ from $d \times s$ & $d \times d$ & 104 & 42 \\
\hline 6 & $\mathrm{~F}_{1}$ from DBA $(\mathrm{d}) \times \mathrm{C}_{3} \mathrm{H}(\mathrm{d})$ & $d \times d$ & 26 & 0 \\
\hline & All $F_{2}$ from $d \times d$ & $d \times d$ & 26 & 0 \\
\hline $\begin{array}{l}7 \\
8\end{array}$ & $\begin{array}{l}\mathrm{F}_{1} \text { from Spl }(\mathrm{s}) \times \mathrm{ur}(\mathrm{s}) \\
\mathrm{F}_{1} \text { from Ki }(\mathrm{s}) \times \text { ur }(\mathrm{s})\end{array}$ & $\begin{array}{l}s \times s \\
s \times s\end{array}$ & $\begin{array}{l}0 \\
0\end{array}$ & $\begin{array}{l}20 \\
18\end{array}$ \\
\hline & All $F_{2}$ from $s \times s$ & $s \times s$ & 0 & 38 \\
\hline
\end{tabular}

* Numbers of experiments correspond to original $F_{1}$ crosses as listed in Table I.
Table II contains the data from further breeding tests, in which individuals of the first hybrid generation $\left(F_{1}\right)$ obtained from crosses of "diffuse" by "single" were crossed inter se (experiments 1 through 5); 146 animals of the second hybrid generation $\left(\mathrm{F}_{2}\right)$ of all five such experiments segregated into 104 with the "diffuse" and 42 with the "single" hemoglobin pattern, a ratio approximating the expected $3: 1 . \mathrm{F}_{2}$ animals from experiment $6(\mathrm{~d} \times \mathrm{d})$ did not segregate: all the offspring gave the "diffuse" hemoglobin pattern. Absence of segregation was found also in the $F_{2}$ animals of experiments 7 and 8 where "single" was crossed by "single" : all 38 offspring gave the "single" pattern.

Table III shows the results of backcrosses of $F_{1}$ animals, derived from crosses of "diffuse" by "single," to their parents with "single" hemoglobin patterns; the offspring segregated for "diffuse" and "single" with a good fit to a $1: 1$ ratio.

In Table IV are summarized the hemoglobin patterns of another group of backcrosses. Here, $F_{2}$ animals, from crosses of "diffuse" by "single," who showed the "diffuse" type (experiments A 1 through 5, B 1 through 5) or the "single" type (experiments C 1 through 5 ) of hemoglobin pattern were backcrossed to their respective grandparents with "single" hemoglobin patterns. Of the $19 \mathrm{~F}_{2}$ animals with "diffuse" hemoglobin pattern, 7 failed to segregate and gave "diffuse" offspring only (experiments A 1 through 5). The other twelve $\mathrm{F}_{2}$ animals (experiments $\mathrm{B} 1$ through 5 ) when backcrossed to the grandparent with "single" hemoglobin pattern gave a segregation of "diffuse" and "single" compatible with a $1: 1$ ratio. The 19 animals of the second hybrid generation thus fell into 2 groups: 12 carrying the factors for both "diffuse" and "single" hemoglobin patterns, and 7 carrying the factor for "diffuse" pattern only, a segregation fitting well a $2: 1$ ratio of carriers to non-carriers. The $\mathrm{F}_{2}$ animals with the "single" type hemoglobin pattern (Table IV, experiments 1 through 5 ), derived from the same crosses of $F_{1}$ animals as their "diffuse" siblings, were backcrossed to animals of the parent strain with "single" pattern and gave offspring with "single" hemoglobin pattern only.

In all experiments, females and males were distributed equally among the different classes of offspring. 


\section{DISCUSSION}

All the results reported here fit the assumption that factors for $d$ (diffuse) and s (single) hemoglobin patterns segregate as simple Mendelian autosomal alleles. The results of crosses of $d \times s$ (Table $I$ ) in the first hybrid $\left(F_{1}\right)$, in the second hybrid generation $\left(F_{2}\right)$ (Table II) as well as in the backcross generations (Tables III and IV) might be interpreted as indicating that $d$ is dominant over s. Although the method of paper electrophoresis employed did not permit distinction of hemoglobin patterns of animals carrying the factors for both the $d$ and the s type from the hemoglobin pattern of animals carrying the factor for $\mathrm{d}$ only, it is conceivable that the hemoglobin composition of $\mathrm{d} / \mathrm{s}$ animals might be distinguished from that of animals homozygous for $d$ by other methods. Further experiments are planned to elucidate this point. The decision between dominance and co-dominance of $d$ and $s$ can therefore not be made at present.

The distribution of hemoglobin patterns of $F_{2}$ animals and of backcrosses of both $F_{1}$ and $F_{2}$ animals to the parent strain with the "single" type hemoglobin pattern is entirely consistent with the
TABLE III

Results of backcrosses of $F_{1}$ generation from $d \times s$ to $s$ strains

\begin{tabular}{lllrr}
\hline \hline Exp.* & Origin of $\mathrm{F}_{1}$ parent & BC parent & \multicolumn{2}{c}{ Offspring } \\
\hline & & & $\mathrm{d}$ & $\mathrm{s}$ \\
2 & from BALB (d) $\times \mathrm{Spl}(\mathrm{s})$ & $\mathrm{Spl}(\mathrm{s})$ & 25 & 21 \\
3 & from Fu (d) Xur (s) & $\mathrm{ur}(\mathrm{s})$ & 16 & 23 \\
5 & from $\mathrm{C}_{3} \mathrm{H}(\mathrm{d}) \times \mathrm{Ki}(\mathrm{s})$ & $\mathrm{Ki}(\mathrm{s})$ & 8 & 9 \\
& \multicolumn{2}{c}{ All $F_{1}$ from $d \times s$ backcrossed to $s$} & 49 & 53
\end{tabular}

${ }^{*}$ Numbers of experiments correspond to original $F_{1}$ crosses as listed in Table I.

assumption that $\mathrm{d}$ and $\mathrm{s}$ behave as alleles segregating in the expected ratios.

Comprehensive data on the genetic aspects of human hemoglobins have been summarized by Neel (4): the genetic aspects of hemoglobins in man are somewhat different from those found in mice. Human hemoglobins are controlled genetically by a group of factors some of which behave as alleles; it seems that each allele is responsible for the presence of one particular hemoglobin. With respect to human hemoglobins, then, an individual homozygous for any one of these genetic factors shows the presence of pre-

TABLE IV

Results of backcrosses of $F_{2}$ generation to strains

\begin{tabular}{|c|c|c|c|c|c|c|c|}
\hline Exp.* & Origin of $F_{2}$ parent & $\begin{array}{c}\text { Hemoglobin } \\
\text { pattern of } \\
\text { parent }\end{array}$ & $\begin{array}{c}\text { Number of } \\
\text { animals } \\
\text { tested }\end{array}$ & BC parent & & \multicolumn{2}{|c|}{ Offspring } \\
\hline A & & & & & & d & $\mathrm{s}$ \\
\hline $\begin{array}{l}1 \\
2 \\
3 \\
5\end{array}$ & $\begin{array}{l}\mathrm{F}_{2} \text { from DBA (d) } \times \mathrm{Ki}(\mathrm{s}) \\
\mathrm{F}_{2} \text { from BALB (d) } \times \mathrm{Spl}(\mathrm{s}) \\
\mathrm{F}_{2} \text { from } \mathrm{Fu}(\mathrm{d}) \times \mathrm{ur}(\mathrm{s}) \\
\mathrm{F}_{2} \text { from } \mathrm{C}_{3} \mathrm{H}(\mathrm{d}) \times \mathrm{Ki}(\mathrm{s})\end{array}$ & $\begin{array}{l}d \\
d \\
d \\
d\end{array}$ & $\begin{array}{l}2 \\
1 \\
3 \\
1\end{array}$ & $\begin{array}{l}\mathrm{Ki}(\mathrm{s}) \\
\mathrm{Spl}(\mathrm{s}) \\
\mathrm{ur}(\mathrm{s}) \\
\mathrm{Ki}(\mathrm{s})\end{array}$ & & $\begin{array}{r}13 \\
3 \\
17 \\
4\end{array}$ & $\begin{array}{l}0 \\
0 \\
0 \\
0\end{array}$ \\
\hline B & A: all non-segregating $F_{2} d$ & & $7=d / d$ & $s$ & & 37 & 0 \\
\hline $\begin{array}{l}1 \\
2 \\
3 \\
4 \\
5\end{array}$ & $\begin{array}{l}\mathrm{F}_{2} \text { from DBA }(\mathrm{d}) \times \mathrm{Ki}(\mathrm{s}) \\
\mathrm{F}_{2} \text { from BALB (d) } \times \mathrm{Spl}(\mathrm{s}) \\
\mathrm{F}_{2} \text { from } \mathrm{Fu}(\mathrm{d}) \times \text { ur }(\mathrm{s}) \\
\mathrm{F}_{2} \text { from } \mathrm{C}_{3} \mathrm{H}(\mathrm{d}) \times \mathrm{Spl}(\mathrm{s}) \\
\mathrm{F}_{2} \text { from } \mathrm{C}_{3} \mathrm{H}(\mathrm{d}) \times \mathrm{Ki}(\mathrm{s})\end{array}$ & $\begin{array}{l}d \\
d \\
d \\
d \\
d\end{array}$ & $\begin{array}{l}4 \\
3 \\
1 \\
1 \\
3\end{array}$ & $\begin{array}{l}\mathrm{Ki}(\mathrm{s}) \\
\text { Spl (s) } \\
\text { ur (s) } \\
\text { Spl (s) } \\
\mathrm{Ki}(\mathrm{s})\end{array}$ & $\cdot$ & $\begin{array}{r}16 \\
11 \\
11 \\
1 \\
6\end{array}$ & $\begin{array}{r}13 \\
9 \\
1 \\
2 \\
8\end{array}$ \\
\hline $\mathrm{C}$ & $\mathrm{B}:$ all segregating $F_{2} d$ & & $12=d / s$ & $s$ & & 45 & 33 \\
\hline $\begin{array}{l}1 \\
2 \\
3 \\
4 \\
5\end{array}$ & $\begin{array}{l}\mathrm{F}_{2} \text { from } \mathrm{DBA}(\mathrm{d}) \times \mathrm{Ki}(\mathrm{s}) \\
\mathrm{F}_{2} \text { from BALB }(\mathrm{d}) \times \mathrm{Spl}(\mathrm{s}) \\
\mathrm{F}_{2} \text { from } \mathrm{Fu}(\mathrm{d}) \times \mathrm{ur}(\mathrm{s}) \\
\mathrm{F}_{2} \text { from } \mathrm{C}_{3} \mathrm{H}(\mathrm{d}) \times \mathrm{Spl}(\mathrm{s}) \\
\mathrm{F}_{2} \text { from } \mathrm{C}_{3} \mathrm{H}(\mathrm{d}) \times \mathrm{Ki}(\mathrm{s})\end{array}$ & $\begin{array}{l}\mathrm{s} \\
\mathrm{s} \\
\mathrm{s} \\
\mathrm{s} \\
\mathrm{s}\end{array}$ & $\begin{array}{l}6 \\
2 \\
1 \\
1 \\
5\end{array}$ & $\begin{array}{l}\text { Ki (s) } \\
\text { Spl (s) } \\
\text { ur (s) } \\
\text { Spl (s) } \\
\text { Ki (s) }\end{array}$ & & $\begin{array}{l}0 \\
0 \\
0 \\
0 \\
0\end{array}$ & $\begin{array}{r}31 \\
13 \\
2 \\
4 \\
18\end{array}$ \\
\hline & $\mathrm{C}:$ all $F_{2} s$ & & $15=s / s$ & $s$ & & 0 & 68 \\
\hline
\end{tabular}

* Numbers of experiments correspond to original $\mathrm{F}_{1}$ crosses as listed in Table $\mathrm{I}$. 


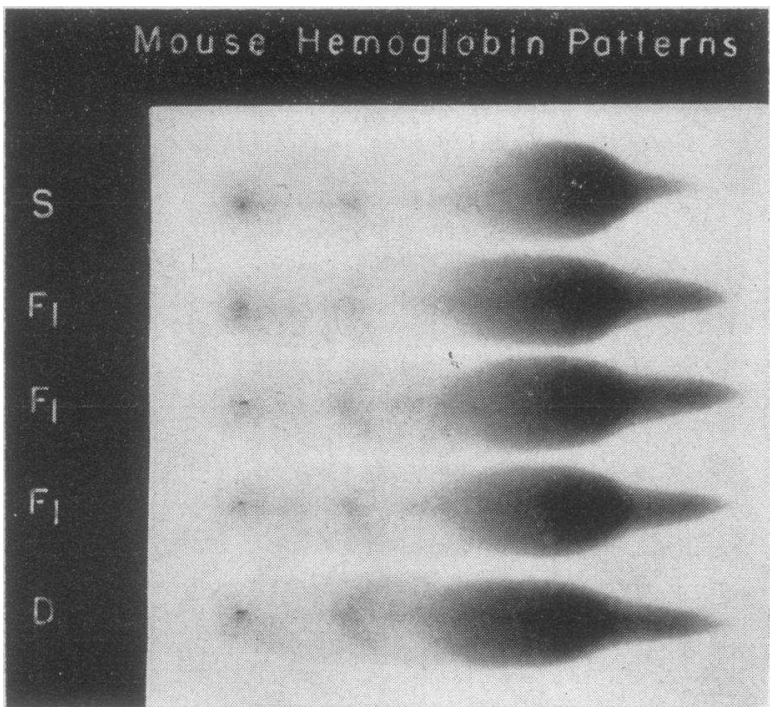

Fig. 1. Paper Electrophoretic Pattern of Hemoglobins of Parents and Offspring

$\mathrm{S}$ is parent with Type I (single) hemoglobin pattern; $\mathrm{D}$ is parent with Type II (diffuse) hemoglobin pattern. All three $F_{1}$ 's are sibs and show Type II pattern.

Paper electrophoresis pattern: 6 hour run, 450 volts, stained with bromphenol blue.

dominantly one type of hemoglobin, whereas an individual heterozygous for any 2 of the allelic genetic factors will have 2 electrophoretically demonstrable different hemoglobins. However, recent studies by Kunkel and Wallenius (5), Morrison and Cook (6), and Schapira, Dreyfus, and Kruh (7) indicate that there may be more than one variety of hemoglobin in the erythrocytes, even of the normal human who is homozygous for the genetic factor for normal human hemoglobin.

In the mouse, the presence of the $s$ allele in homozygous condition is accompanied by the presence of only one type of hemoglobin pattern, i.e., the "single" type. Animals homozygous for the $\mathrm{d}$ allele demonstrate the "diffuse" type of hemoglobin pattern which may, however, be a mixture of hemoglobins rather than one hemoglobin. The individual heterozygous for $\mathrm{d}$ and s shows the same hemoglobin pattern electrophoretically as does the $\mathrm{d}$ homozygote. It would appear particularly interesting if a mixture of hemoglobins as is perhaps present in the $d$ homozygote were controlled by one genetic unit; this situation would be different from that of the abnormal hemoglobins in man where each allele manifests itself by the presence of one hemoglobin.

\section{SUMMARY}

The hereditary transmission of hemoglobin differences in mice has been investigated by the method of paper electrophoresis.

Crosses between strains with two different electrophoretic hemoglobin patterns, "diffuse" (d) and "single" (s), show that the genetic factors for the 2 patterns segregate as simple Mendelian autosomal alleles.

The methods employed in this investigation do not permit differentiation of the electrophoretic hemoglobin pattern of mice of the first hybrid generation, heterozygous for "diffuse" and "single" $(\mathrm{d} / \mathrm{s})$, from the "diffuse" pattern of the parent, homozygous for "diffuse" (d/d).

The hereditary control of hemoglobin differences in the mouse appears to differ from that of abnormal hemoglobins in man.

\section{REFERENCES}

1. Ranney, H. M., and Gluecksohn-Waelsch, S., Filterpaper electrophoresis of mouse haemoglobin; preliminary note. Ann. of Human Genet., 1955, 19, 269.

2. Larson, D. L., and Ranney, H. M., Filter paper electrophoresis of human hemoglobin. J. Clin. Invest., 1953, 32, 1070 .

3. Standardized Nomenclature for Inbred Strains of Mice. Cancer Research, 1952, 12, 602.

4. Neel, J. V., The genetics of human haemoglobin differences: problems and perspectives. Ann. of Human Genet., 1956, 21, 1.

5. Kunkel, H. G., and Wallenius, G., New hemoglobin in normal adult blood. Science, 1955, 122, 288.

6. Morrison, M., and Cook, J. L., Chromatographic fractionation of normal adult oxyhemoglobin. Science, $1955,122,920$.

7. Schapira, G., Dreyfus, J.-C., and Kruh, J., Recherches sur la synthèse des hémoglobines humaines étudiée à l'aide du fer radioactif. Gior. Biochimiche, 1955, Suppl. Ricerca scient., anno $25^{\circ}, 132$. 